\title{
Role of poly (ADP-ribose) polymerase-1 and NF-kappaB as potential risk factor in the development of non-small cell lung cancer in Chinese individuals
}

\author{
Anguo Chen'1, Zaicheng Yu¹, Renquan Zhang1, Qihong Zhao² and Jianjun Ge3 \\ ${ }^{1}$ Department of Thoracic Surgery, The First Affiliated Hospital of Anhui Medical University, Hefei, Anhui, 230022, \\ China; ${ }^{2}$ Department of Food and Nutrition Hygiene, School of Public Health, Anhui Medical University, Hefei, Anhui, \\ 230 032, China; ${ }^{3}$ Department of Cardiovascular Surgery, The Anhui Provincial Hospital of Anhui Medical University, \\ Hefei, Anhui 230001 , China.
}

\begin{tabular}{l} 
Article Info \\
\hline Received: $\quad$ 17 September 2017 \\
Accepted: $\quad$ 22 September 2017 \\
Available Online: $\quad$ 30 January 2017 \\
DOI: 10.3329/bjp.v13i1.34031 \\
Cite this article: \\
Chen A, Yu Z, Zhang R, Zhao Q, Ge J. \\
Role of poly (ADP-ribose) polymerase \\
-1 and NF-kappaB as potential risk \\
factor in the development of non- \\
small cell lung cancer in Chinese indi- \\
viduals. Bangladesh J Pharmacol. \\
2018; 13: 30-34.
\end{tabular}

\section{Abstract}

The objective of this study was to evaluate the role of poly (ADP-ribose) polymerase-1 (PARP-1) and NF-kappaB as potential risk factor in the development of non-small cell lung cancer in Chinese individuals $(n=110)$ of either gender aged $<65$ years. Healthy Chinese individuals $(n=110)$ were included as control. Polymerase chain reaction was used to determine the role of PART-1 and NF-kappaB using plasma sample. The individuals with the GA genotype and carrier of $G$ allele were at high-risk of non-small cell lung cancer. There was involvement of $\mathrm{dL} /$ is of the NF-kappaB in non-small cell lung cancer. Our study result suggests that the PARP-1 and NF-kappaB play an important role in development of non-small cell lung cancer in China.

\section{Introduction}

Lung cancer is one of the important causes of mortality worldwide (Park et al., 2015; Masuda et al., 2015). Nonsmall cell lung cancer is the most common subtype, accounting for approximately $80-85 \%$ of all lung cancers (Park et al., 2015; Masuda et al., 2015). Most patients with non-small cell lung cancer are diagnosed at the advanced stages (stages IIIb and IV), with only 16-30\% diagnosed in the early stages of the disease (Park et al., 2015; Masuda et al., 2015; Polanski et al., 2016). Patients diagnosed with advanced non-small cell lung cancer generally have a poor prognosis, with a median survival of 8-10 months and 2 and 5-year survival rates of approximately $20 \%$ and $15 \%$, respectively (Park et al., 2015; Masuda et al., 2015; Polanski et al., 2016; Ali et al., 2013).

Poly (ADP-ribose) polymerase-1 (PARP-1) is also known as adenosine diphosphate-ribosyltransferases catalyses the process of PARylation by attaching the polymers of ADP-ribose on target protein motif via ester linkage and trigger the array of vital cellular functions viz. chromatin structure, DNA repair, transcriptional regulation, apoptosis, necrosis, cell separation and differentiation. In human, 17 members of PARP-1 are expressed, of which NAD+ ADP-ribosyltransferase is associated with the nucleus and regulates at least $85 \%$ of the cellular NAD+ ADP-ribosyltransferase activities (Hur et al., 2006; Smulson et al., 2000; Corcoran et al., 2016; Hassa et al., 2008; Phulwani et al., 2008). PARP-1 maintains the genomic integrity by PARylation of histones and other key enzymes, DNA repair mechanism, interprotein interactions and gene expression to ensure optimum cellular homeostasis (Ba et al., 2011; Chiarugi et al., 2003; Yu et al., 2002). However, throughout the cellular and/or genotoxic stress, prolong activation of 
PARP-1 lead to decrease in $\beta$-nicotinamide adenine dinucleotide $\left(\mathrm{NAD}^{+}\right)$and adenosine triphosphate (ATP), and causes release of mitochondrial proapoptotic protein, apoptosis-inducing factor (AIF). Such stress-induced dysregulation in cellular homeostasis mediated by PARP-1, triggers the downstream necrosis cascade of cell death (Ba et al., 2011; Chiarugi et al., 2003).

The functional role of PARP-1 and NF-kappaB in the non-small cell lung cancer was not evaluated among Chinese individuals. The objective of this study was to ascertain whether PARP-1 and NF-kappaB are involved in the development of non-small cell lung cancer among Chinese individuals.

\section{Materials and Methods}

\section{Subjects}

Patients of both genders aged $<65$ years with a confirmed diagnosis of non-small cell lung cancer $(n=110)$ and healthy individuals $(n=110)$ were recruited. The study protocol was approved by the Ethics Committee of the Anhui Provincial Hospital of the Anhui Medical University. The written informed consent was taken from each study subject. All subjects were educated about the study protocol and the likely benefits to the society. All participants undergone laboratory tests or required investigation to confirm their eligibility for this study.

\section{Assessments}

Plasma samples were collected from the study population and the DNA from leukocytes was extracted by the high salt DNA extraction method. All isolated DNA samples were kept at $-80^{\circ} \mathrm{C}$ for further assessment. Using efficient molecular biology techniques, polymerphisms of the PARP-1 and NFkB genes were studied in DNA samples by polymerase chain reaction-restriction fragment length polymorphism (PCR-RFLP) analysis. PCR-RFLP was performed using an optimized sequence of cycles: A denaturation phase at $95^{\circ} \mathrm{C}(2 \mathrm{~min})$ followed by 30 cycles at $95^{\circ} \mathrm{C}(30 \mathrm{sec}), 60^{\circ} \mathrm{C}$ (30 sec), $72^{\circ}$ $\mathrm{C}(1 \mathrm{~min})$, and a final incubation phase at $72^{\circ} \mathrm{C}(5 \mathrm{~min})$. The PCR products were treated with $5 \mathrm{U}$ of HpyF3I (DdeI) (fermentas) and Bsh1236I (fermentas) at $37^{\circ} \mathrm{C}$ overnight for digestion. The resulting fragments were run on ethidium bromide-stained 3\% agarose gel for 45 min at $90 \mathrm{~V}$ and quantified through direct detection under ultraviolet light. Likewise, the NFkB genes were amplified by 285 and 424 base-pair PCR fragments using the same reagents. The PCR running sequence included a denaturing step at $95^{\circ} \mathrm{C}(1 \mathrm{~min})$ followed by 35 cycles at $95^{\circ} \mathrm{C}(30 \mathrm{~s}), 61^{\circ} \mathrm{C}(30 \mathrm{~s}), 72^{\circ} \mathrm{C}(1 \mathrm{~min})$ and $\mathrm{a}$ final incubation at $72^{\circ} \mathrm{C}(5 \mathrm{~min})$. The PCR products were treated with $5 \mathrm{U}$ PflMI (Van91I) and HaeIII (BsuRI) (Fermentas) at $37^{\circ} \mathrm{C}$ overnight for digestion and the digested products were run on ethidium bromidestained $3 \%$ agarose gel for $45 \mathrm{~min}$ at $90 \mathrm{~V}$ and quantified directly under UV light.

\section{Statistical analysis}

Normality of data was checked using KM or SW test, and interpretation is solely depends on the results of $p$ value of SW/KM test which confirm the normality of the data. Data which follow bell shaped or Gaussian distribution were test using parametric test such as unpaired ' $t$ ' test for between group comparison, and if data not following the bell shaped or Gaussian distribution, then data were analyzed using Mann-Whitney U test or non-parametric test based on the number of treatment groups. Numerical variable was presented as mean (standard deviation). Qualitative outcome were presented as absolute number (percentage) of individuals in each category. Data from each patient was coded and analyzed using GraphPad Prism statistical analysis software (version 6.0). Quantitative variable was presented as mean (standard deviation), and analyzed by parametric/non-parametric statistical test based number of comparison group and distribution of data, using 2-sided statistical tests. Categorical variables were presented as absolute number and/or percentage of subjects in each category, and analyzed by Chisquare or fisher exact test based on size of data, using 2sided statistical tests. Odd ratio was calculated using Chi-square or fisher exact statistical test.

\section{Results}

\section{Demography and clinical characteristics}

The mean (SD) age of the patients of non-small cell lung cancer was 32.8 (2.3), whereas it was 36.5 (2.4) year in healthy subjects (Table I).

\section{Primary and secondary endpoints results}

The individuals with GA gene were at susceptible of

\begin{tabular}{|l|ccc|}
\hline \multicolumn{4}{|c|}{ Table I } \\
\hline \multicolumn{5}{|c|}{ Demographic characteristics } \\
\hline Variables & $\begin{array}{c}\text { Patients } \\
(\mathrm{n}=110)\end{array}$ & $\begin{array}{c}\text { Healthy subjects } \\
(\mathrm{n}=110)\end{array}$ & $\begin{array}{c}\mathrm{p} \\
\text { value }\end{array}$ \\
\hline Age & 32.8 & 36.5 & $>0.005$ \\
& $(2.3)$ & $(2.4)$ & \\
Gender & & & $>0.005$ \\
Men & 85 & 80 & $>0.005$ \\
Women & 25 & 30 & $>0.005$ \\
BMI & 24.16 & 22.53 & \\
\hline Data are mean $( \pm$ SD $)$ & $(3.2)$ & \\
\hline
\end{tabular}


Table II

Genotypes involved in patients of non-small cell lung cancer

\begin{tabular}{|c|c|c|c|c|}
\hline Sequence & $\begin{array}{r}\text { Patients } \\
(\mathrm{n}=110)\end{array}$ & $\begin{array}{l}\text { Healthy } \\
\text { subjects } \\
(n=110)\end{array}$ & $\begin{array}{l}\text { Odd ratio } \\
(95 \% \mathrm{CI})\end{array}$ & $\mathrm{p}$ value \\
\hline \multicolumn{5}{|c|}{ G1672A genotype } \\
\hline GG & 46 & 43 & $\begin{array}{r}1.5 \\
(0.7-3.3)\end{array}$ & 0.32 \\
\hline GA & 84 & 46 & $\begin{array}{r}2.4 \\
(1.2-3.1)\end{array}$ & 0.004 \\
\hline AA & 43 & 42 & $\begin{array}{r}1.5 \\
(0.7-2.4)\end{array}$ & 0.63 \\
\hline \multicolumn{5}{|c|}{ G1672A genotype } \\
\hline G Allele & 213 & 121 & \multirow[t]{2}{*}{$\begin{array}{r}2.8 \\
(1.3-3.1)\end{array}$} & \multirow[t]{2}{*}{$<0.001$} \\
\hline A Allele & 27 & 32 & & \\
\hline \multicolumn{5}{|c|}{ C410T genotype } \\
\hline $\mathrm{CC}$ & 43 & 42 & $\begin{array}{r}1.1 \\
(0.3-2.3)\end{array}$ & 0.08 \\
\hline $\mathrm{CT}$ & 67 & 71 & $\begin{array}{r}1.1 \\
(0.1-1.2)\end{array}$ & 0.068 \\
\hline TT & 98 & 89 & $\begin{array}{r}1.4 \\
(0.2-1.4)\end{array}$ & 0.079 \\
\hline \multicolumn{5}{|c|}{ Allele-C410T } \\
\hline C Allele & 76 & 38 & \multirow{2}{*}{$\begin{array}{r}2.3 \\
(1.3-2.7)\end{array}$} & \multirow[t]{2}{*}{0.002} \\
\hline T Allele & 34 & 39 & & \\
\hline \multicolumn{5}{|c|}{ NF-кB1 genotype } \\
\hline Ins/ins & 21 & 28 & 3.1 & \\
\hline del/ins & 11 & 26 & $\begin{array}{r}2.8 \\
(1.3-3.2)\end{array}$ & 0.23 \\
\hline del/del & 23 & 21 & $\begin{array}{r}2.2 \\
(2.2-2.9)\end{array}$ & 0.19 \\
\hline \multicolumn{5}{|c|}{ Allele-NF-кB1 } \\
\hline Ins & 54 & 65 & \multirow{2}{*}{$\begin{array}{r}3.2 \\
(2.4-3.3)\end{array}$} & \multirow[t]{2}{*}{0.073} \\
\hline Del & 43 & 47 & & \\
\hline \multicolumn{5}{|c|}{$N F-\kappa B I A$ - genotype } \\
\hline AA & 56 & 57 & 1.2 & \\
\hline AG & 89 & 79 & $\begin{array}{r}3.5 \\
(2.4-3.6)\end{array}$ & 0.05 \\
\hline GG & 76 & 67 & $\begin{array}{r}2.4 \\
(2.4-2.2)\end{array}$ & 0.068 \\
\hline \multicolumn{5}{|c|}{ Allele involved in NF- $\kappa B I A$} \\
\hline AA & 231 & 239 & $\begin{array}{r}2.2 \\
(3.3-3.4)\end{array}$ & 0.22 \\
\hline AG & 39 & 42 & & \\
\hline
\end{tabular}

developing non-small cell lung cancer. The risk of nonsmall cell lung cancer was higher in patients who had GA gene compared to subjects who had no GA gene $(p<0.001)$. The individuals with $G$ allele were also susceptible for higher risk of non-small cell lung cancer; risk of non-small cell lung cancer was higher in patients who had $G$ allele compared to subjects who had no $G$ allele $(p<0.001)$. The individuals with $C$ allele were more susceptible of non-small cell lung cancer (Table II). There was positive relationship of PARP-1 with nonsmall cell lung cancer. Among patients of non-small cell lung cancer, del/ins of nuclear factor-kB1 gene was found associated. This suggest role of del/ins of nuclear factor-kB1 in progression of non-small cell lung cancer. Association of del/ins of NF-kB1 was observed with non-small cell lung cancer. However, there was no statistical significant association was observed among other genotype of nuclear factor-kB1 gene with nonsmall cell lung cancer. Our finding suggested that there was significant association of polymorphism of PARP-1 and nuclear factor-KB1 in patients of non-small cell lung cancer as compared to healthy subjects (Table II).

\section{Discussion}

To the best of knowledge, this is the first study to determine involvement of PARP-1 and NF-kappaB in individuals with non-small cell lung cancer. In this study, the individuals with GA gene were at higher risk of non-small cell lung cancer as compared to subjects who had no GG gene. Also it was observed that the individuals with $\mathrm{C}$ and $\mathrm{G}$ allele are also susceptible of non-small cell lung cancer. This indicates the positive relationship of PARP-1 polymorphisms. In addition, among patients of non-small cell lung cancer, polymorphism of del/ins of nuclear factor-kB1 gene was found associated. This indicates the involvement of $\mathrm{del} /$ ins of nuclear factor-kB1 in development of nonsmall cell lung cancer. The results of this study suggested that there was significant association of polymorphism of PARP-1 and nuclear factor- $\mathrm{kB1}$ in patients of non-small cell lung cancer as compared to healthy subjects. Zhong et al. have demonstrated a novel, significant correlation between the hOGG1 Ser326Cys polymorphism and increased lung cancer susceptibility in Caucasians. Authors of this study have indicated a need for larger-scale studies to verify the association of this SNP with lung cancer risk in Caucasians (Zhong D, 2012). Another study showed lymorphic variations in TP53 represent attractive candidate susceptibility alleles for lung cancer. In this study, authors have showed the accosiation of MspI RFLP and 16 bp duplication polymorphism in increasing the risk of lung cancer (Matakidou, 2003).

In this study, individuals with a GG genotype and carriers of a $G$ allele were more susceptible to and at very high risk of developing non-small cell lung cancer. This indicates that a GA genotype might have a defensive influence on the disease. The possible reason for involvement of the GG genotype as a risk factor for 
non-small cell lung cancer could be explained by molecular heterosis, which is observed in approx. 50\% of cases of gene associations (Comings, 2000). Also it was observed the involvement of a NF-kB1 polymerphism in the increased risk of non-small cell lung cancer. This study results showed involvement of PARP -1 and NF-KB in non-small cell lung cancer indicates PARP-1 and NF-KB as a promising therapeutic target in clinical treatment of non-small cell lung cancer. In addition, previous study demonstrated that PARP-1 inhibitors inhibit apoptotic cell death in neuronal tissue by preventing the activation of the apoptosis pathway (Yu, 2005). In addition, reports indicate that PARP-1 inhibitors have strong anti-inflammatory properties resulting in reduced 1) polymorphonuclear leukocyte infiltration, 2) activation of NF-KB, and 3) degree of tissue injury (Comings, 2000; $\mathrm{Yu}, 2005$; Chiarugi A 2002; Scott GS, 1999). Differential expression of the desired gene product in the target tissue is central to the concept of gene therapy (Trofimova, 2002). The development of potent PARP-1 inhibitors has become of increasing clinical interest in various disease conditions. This study results suggest that the PARP inhibitorbased gene therapy as a new treatment paradigm for non-small cell lung cancer. This study results provide proof-of-principle for a novel therapeutic strategy for the treatment of non-small cell lung cancer.

This was the first study to suggest the association of 2 single nucleotide polymorphisms (SNPs) of PARP-1 (C410T and G1672A) with non-small cell lung cancer. The involvement of these SNPs in non-small cell lung cancer has not yet been established. Since PARP-1 catalyzes poly (ADP-ribosyl)ation to various proteins involved in many cellular processes, including DNA damage detection and repair, and cell proliferation and death $(\mathrm{Yu}, 2002)$. Several reports showed the involvement of polymorphisms of PARP-1 in susceptibility of developing various diseases such as cancer, cataract (Cui, 2017) and Graves' disease (Niyazoglu, 2014). Thus, finding of this study encourages the researchers to focus on two SNPs of PARP-1 (C410T and G1672A) in other disease conditions. Since the study was designed as pilot study and conducted at single study center in China (limitation of study). Therefore, the present findings cannot be generalized to the overall Chinese population. Based on the study results, study results encourage for conducting large multi-centric randomized clinical study in future to generalize the findings of this study. The hypothesis of this study for relationship between PARP-1 and NFkB with non-small cell lung cancer was met. Overall, results showed the polymorphism of PARP-1 and nuclear factor-kB1 is involved in development of non-small cell lung cancer in Chinese individuals

\section{Conclusion}

The study result showed the involvement of PARP-1 and NFkB in development of non-small cell lung cancer among Chinese individuals.

\section{Acknowledgement}

All authors would like to thank the subjects for their participation in this study.

\section{References}

Ali A, Goffin JR, Arnold A, Ellis PM. Survival of patients with non-small cell lung cancer after a diagnosis of brain metastases. Curr Oncol. 2013; 20: e306.

Ba X, Garg NJ. Signaling mechanism of poly (ADP-ribose) polymerase-1 (PARP-1) in inflammatory diseases. Am J Pathol. 2011; 178: 946-55.

Chiarugi A. Poly(ADP-ribose) polymerase: Killer or conspirator? The `suicide hypothesis' revisited. Trends Pharmacol Sci. 2002; 23: 122-29.

Chiarugi A, Moskowitz MA. Poly (ADP-ribose) polymerase-1 activity promotes NF-kappaB-driven transcription and microglial activation: implication for neurodegenerative disorders. J Neurochem. 2003; 85: 306-17.

Comings DE, MacMurray JP. Molecular heterosis: A review. Mol Genet Metab. 2000; 71: 19-31.

Corcoran NM, Clarkson MJ, Stuchbery R, Hovens CM. Molecu -lar pathways: Targeting DNA repair pathway defects enriched in metastasis. Clin Cancer Res. 2016; 22: 3132-37.

Cui NH, Qiao C, Chang XK, Wei L. Associations of PARP-1 variant rs1136410 with PARP activities, oxidative DNA damage, and the risk of age-related cataract in a Chinese Han population: A two-stage case-control analysis. Gene 2017; 600: 70-76.

Hassa PO, Hottiger MO. The diverse biological roles of mammalian PARPS, a small but powerful family of poly-ADPribose polymerases. Front Biosci. 2008; 13: 3046-82.

Hongping Yu, Hongxia Ma, Ming Yin, and Qingyi Wei. Association between PARP-1 V762A polymorphism and cancer susceptibility: A meta-analysis. Genet Epidemiol. 2012; 36: 56-65.

Hur JW, Sung YK, Shin HD, Park BL, Cheong HS, Bae SC. Poly (ADP-ribose) polymerase (PARP) polymorphisms associated with nephritis and arthritis in systemic lupus erythematosus. Rheumatology (Oxford) 2006; 45: 711-17.

Masuda T, Imai H, Kuwako T, Miura Y, Yoshino R, Kaira K, Shimizu K, Sunaga N, Tomizawa Y, Ishihara S, Mogi A, Hisada T, Minato K, Takise A, Saito R, Yamada M. Efficacy of platinum combination chemotherapy after first-line gefitinib treatment in non-small cell lung cancer patients 
harboring sensitive EGFR mutations. Clin Transl Oncol. 2015; 17: 702-09.

Matakidou A1, Eisen T, Houlston RS. TP53 polymorphisms and lung cancer risk: A systematic review and meta-analysis. Mutagenesis 2003; 18: 377-85.

Niyazoglu M, Baykara O, Koc A, Aydoğdu P, Onaran I, Dellal FD, Tasan E, Sultuybek GK. Association of PARP-1, NF-kB, NF-kBIA and IL-6, IL-1 $\beta$ and TNF- $\alpha$ with Graves disease and Graves ophthalmopathy. Gene 2014; 547: 226-32.

Park S, Keam B, Kim SH, Kim KH, Kim YJ, Kim JS, Kim TM, Lee SH, Kim DW, Lee JS, Heo DS. Pemetrexed singlet versus non-pemetrexed-based platinum doublet as second-line chemotherapy after first-line epidermal growth factor receptor (EGFR) tyrosine kinase inhibitor failure in nonsmall cell lung cancer patients with EGFR mutations. Cancer Res Treat. 2015; 47: 630-37.

Phulwani NK, Kielian T. Poly (ADP-ribose) polymerases (PARPs) 13 regulate astrocyte activation. J Neurochem. 2008; 106: 578-90.

Polanski J, Jankowska-Polanska B, Rosinczuk J, Chabowski M,
Szymanska-Chabowska M. Quality of life of patients with lung cancer. Onco Targets Ther. 2016; 9: 1023-28.

Scott GS, Jakeman LB, Stokes BT, Szabó C. Peroxynitrite production and activation of poly (adenosine diphosphateribose) synthetase in spinal cord injury. Ann Neurol. 1999; 45: $120-24$.

Smulson ME, Simbulan-Rosenthal CM, Boulares AH, et al. Roles of poly(ADP-ribosyl)ation and PARP in apoptosis, DNA repair, genomic stability and functions of p53 and E2F1. Adv Enzyme Regul. 2000; 40: 183-215.

Trofimova I, Dimtchev A, Jung M, Rosenthal D, Smulson M, Dritschilo A, Soldatenkov V. Gene therapy for prostate cancer by targeting poly(ADP-ribose) polymerase. Cancer Res. 2002; 62: 6879-83.

Yu SW, Wang H, Poitras MF, et al. Mediation of poly (ADP-ribose) polymerase-1-dependent cell death by apoptosis-induc -ing factor. Science 2002; 297: 259-63.

Zhong D, Li G, Long J, Wu J, Hu Y. The hOGG1 Ser326Cys polymorphism and increased lung cancer susceptibility in Caucasians: An updated meta-analysis. Sci Rep. 2012; 2: 548. 